\title{
The Greek Perfect through Gothic Eyes: Evidence for the Existence of a Unitary Semantic for the Greek Perfect in New Testament Greek
}

\author{
Robert Crellin \\ Greek Bible College, Athens \\ robertcrellin@cantab.net
}

\begin{abstract}
The semantics of the later Koine Greek perfect have been the subject of considerable debate in recent years. For the immediately post-Classical language Haug (2004) has suggested that the perfect combines resultant state and $\mathrm{XN}$ semantics, unifiable under the framework of event realisation (Bohnemeyer \& Swift 2004). The present article presents a modified unitary semantic in terms of participant property (Smith 1997), and assesses its validity with reference to the translation of the perfect indicative active into Gothic. It is found that, while non-state verbs are translated only with past-tense forms in Gothic, contrary to traditional and even many modern views of the Greek perfect, the perfect of both pure state and change-of-state verbs are compatible with both past and non-past tense readings. The fact that this is the case regardless of the diachronic pedigree of the perfect forms concerned is taken as evidence consistent with the existence of the proposed unitary semantic for the Greek perfect in the New Testament in the eyes of the Gothic translator.
\end{abstract}

\section{Keywords}

Greek - Gothic - verb system - translation - perfect - aspect - tense - anteriority Extended Now - resultant state - pure state 
What may be said to be the underlying semantics of the later Koine Greek perfect? ${ }^{1}$ Indeed, may this morphological category be said to have any unifying semantics at all? Cross-linguistically, the placing of the perfect within a tense-aspectual $^{2}$ framework is widely debated, with opinions ranging between seeing the perfect as another aspect, or as something else entirely. ${ }^{3}$ Part of the difficulty has been the variety of functions and semantics associated with morphological entities given the label 'perfect' across languages (Comrie 1976:53), as well as the semantic instability of the category diachronically. ${ }^{4}$ Linguistic analysis of the perfect has tended to focus on its manifestation in English, and therefore a lot of the framework for discussing it has emerged for the purpose of describing the English perfect. A variety of both complementary and competing analyses of the semantics of the perfect have emerged in recent years: ${ }^{5}$
i. Resultative $^{6}$
ii. Anterior $^{7}$
iii. $\quad$ Extended Now $(\mathrm{XN})^{8}$
iv. Participant property ${ }^{9}$

1 This article is the result of research conducted for a paper of the same name given at the Society of Biblical Literature International Meeting in July 2013. My thanks go to Hans Förster for reading the article and for his comments, as well as to the two anonymous JGL reviewers, whose questions, comments and suggestions have certainly improved the article.

2 For the purposes of this article I take the category 'tense' to be the 'grammaticalised expression of location in time' (Comrie 1985:9). While tense is a deictic category, aspect is non deictic and expresses 'different ways of viewing the internal temporal constituency of a situation' (Comrie 1976:3). Whether the perfect is viewed within the rubric of tense or aspect depends largely on the extent to which it is seen as a deictic category.

3 As in Comrie (1976:52-65), who does not distinguish between the experiential perfect and the perfect of current relevance; see also Bentein (2012:175-182).

4 See e.g. Bybee et al. (1994:68f.).

5 Indeed, some scholars restrict the term 'perfect' to anterior function. So Cutrer (1994), cited by Bentein (2012:175 n. 11), and Bybee et al. (1994:55).

6 Resultatives are often dealt with in their own right, e.g. Nedjalkov (1988).

7 Within 'anterior' are also often identified the following sub-types: current relevance, experiential, persistence and recent past, for which see Bentein (2012:175-182).

8 McCoard (1978:123). For an analysis of the Ancient Greek perfect according to this model see Gerö \& von Stechow (2003).

9 Smith (1997:107) defines the participant property as follows: 'Perfect sentences ascribe to their subjects a property that results from their participation in the prior situation.' 
The Greek perfect is no exception in resisting straightforward analysis of the perfect within its aspectual system. The present paper sets out to test a particular proposal for the semantics of the Greek perfect in the New Testament by assessing its translation into Gothic in the fourth century translation of Bishop Wulfila.

The paper is structured as follows. The current section introduces the problem of the Greek perfect and proposes a particular semantic value for it in the post-Classical period. $\S 2$ assesses the basis on which Wulfila's interpretation of the Greek verb system might be considered reliable. After $\S 3$ briefly outlines the different textual sources used for the investigation, $\S 4$ outlines the structure of the Gothic verb system, while $§ 5$ goes on to outline in detail the method by which the translation of the Greek perfect active is assessed through the Gothic verb system. The results for the tense reading of the perfect are given in $\S 6$. The evidence for a unitary semantic for the Greek perfect is explored in $\S 7$, and final conclusions are drawn in $\S 8$.

The principal problem for the Greek perfect is that, although bearing the label perfect, the range of use of the Greek perfect is very broad. Specifically, in both the Classical and the post-Classical language, ${ }^{10}$ the Greek perfect appears able to denote:

i. Anterior, i.e. 'a past action with current relevance' (Bybee et al. 1994:61).

ii. Resultant state, ${ }^{11}$ i.e. a state resulting from an event prior to reference time.

iii. State concurrent with the reference time of the clause with no reference to any prior event.

The following examples give perfects in the post-Classical period performing each of these functions:

10 Regarding the Classical Greek perfect see Sicking \& Stork (1996), Gerö and Stechow (2003), Haug (2004), Haug (2008), and Orriens (2009). For recent work on the periphrastic perfect, see Bentein (2012). For work on the diachronic development of the Greek perfect see e.g. Wackernagel (1904), Chantraine (1927), Haspelmath (1992), Haug (2008). The post-Classical Greek perfect has principally been studied in the context of the New Testament, separately e.g. McKay (1981), and within the frame of the verb system as a whole, e.g. Porter (1989), Fanning (1990), Evans (2001) and most recently Campbell (2007). For a review of Campbell's views see Crellin (2012a). McKay $(1965,1980)$ concern the perfect outside the New Testament.

11 Here a narrow definition of the term state is adopted, equivalent to Parsons' Target state (Parsons 1990). 


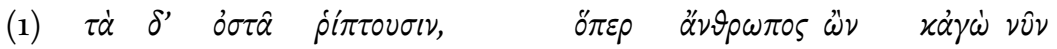
the but bones they-throw.PRES which man being I-too now $\pi \varepsilon \pi 0_{i} \eta x \alpha$.

\section{I-do.PERF}

'... but [men] throw away the bones, as I too who am a man have just done.'

JOS. AJ 12.213; Text: NIESE, 1892 provided by the Perseus Project (http://www .perseus.tufts.edu)

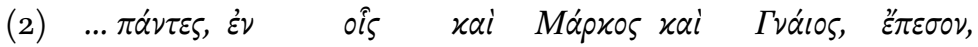
... all among whom both Marcus CONJ Gnaeus fall.AOR-IND

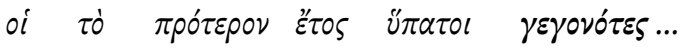
the $_{1}$ the $_{2}$ previous year consuls $_{1}$ become.PERF-PTPL

'... finally all fell, among whom were Marcus and Gnaeus, who had been consuls for the preceding year ...'

PLB. 3.116.11; Text: BUTTNER-WOBST, 1893- provided by the Perseus Project (http:// www.perseus.tufts.edu)

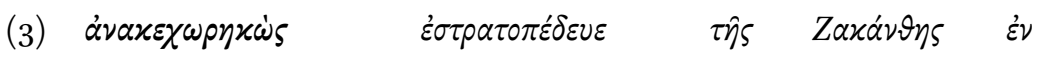
withdraw.PERF-PTPL encamp.IMPF-IND of-the of-Zakanthe in

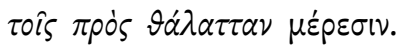

the at sea parts

'... he withdrew and encamped in the parts of Zakanthe that are near the sea.'

PLB. 3.98.5; Text: PERRIN, 1914 provided by the Perseus Project (http://www .perseus.tufts.edu)

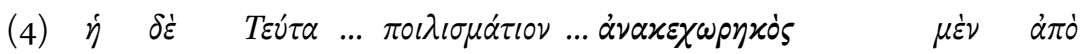
the PTCL Teuta ... small town ... withdraw.PERF-PTPL PTCL from

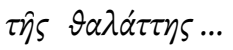

the sea ...

'Teuta ... a small town ... withdrawn from the sea ...'

PLB. 2.11.16, Text: PERRIN, 1914 provided by the Perseus Project (http://www .perseus.tufts.edu)

In (1), because there is a pile of bones in front of Hyrcanus, along with the fact that he is talking, and, therefore, probably not eating, it is clear that he is describing an event which has recently terminated, i.e. an anterior. Similarly,

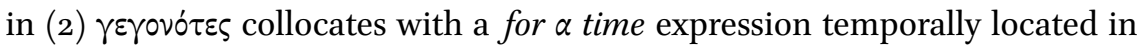
the year prior to that being referred to at reference time. Both the change- 
of-state event and the resultant post-state, therefore, are presented as terminating prior to reference time, and consequently this perfect is understood as an anterior too. In (3), by contrast, the grammatical subject is envisaged as going from a position of not being withdrawn to being withdrawn, and is

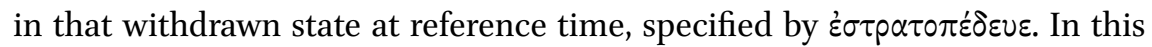
case, therefore, the perfect denotes resultant state. Example (4) is perhaps the most surprising, given that it involves the change-of-state verb $\alpha \nu \alpha \chi \omega \rho \varepsilon ́ \omega$ 'to withdraw', which we might expect to denote resultant state, as it did in (3). However, in this example, the subject is a town. It is very clear, therefore, that the town itself can never have 'withdrawn'. Rather, the perfect must refer to the state of the town at reference time, i.e. 'at some distance from the sea.' ${ }^{12}$

The fact that the perfect demonstrates such a wide range of meanings makes it very difficult to attribute one semantic that might be said to apply in all cases, and leads to all four of the frameworks outlined above failing in the case of the Greek perfect:

i. Resultative: fails to account for examples (1) and (2) where there is no resultant state ${ }^{13}$ for the subject participant that holds at reference time.

ii. Anterior: fails to account for example (4), where there is no reference to any time prior to reference time.

iii. Extended Now: given that the definition includes reference to time prior to reference time, ${ }^{14}$ this analysis suffers from the same weakness as the anterior analysis, namely in not being able to account for example (4).

iv. Participant property: given that the definition asserts that the subject has participated in a prior event, ${ }^{15}$ this explanation will not hold for example (4).

The possibility that the Greek perfect in the time of the NT did not have a unitary semantic synchronically should not a priori be discounted, given that retention is not uncommon. ${ }^{16}$ Nevertheless, it is clearly the case that the more

12 Similar is the case of $\pi \varepsilon p \iota \varepsilon \sigma \tau \varepsilon \varphi \alpha \dot{\alpha} \omega x \varepsilon \nu$ (Jos. AJ 15.337), which, with $\alpha \pi$ ó $\beta \alpha \sigma \varsigma \varsigma$ 'landing area' as its subject, is incompatible with reference to any prior event. The same may be

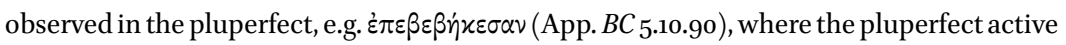
combines with adverbial है $\tau$, blocking reference to any prior event.

13 That is, Parsons' (1990) target state.

14 See n. 8.

15 See n. 9 .

16 I would like to thank an anonymous JGL reviewer for making this point. 
data an account of the semantics of the perfect is able to describe, the more satisfactory that account may be considered to be.

All the analyses so far considered assume the existence of a terminating or culminating event prior to reference time. As noted, however, there are Greek perfects attested in this period which appear not to carry any reference to such an event. Indeed, in extreme cases, as in (4) above involving $\alpha \nu \alpha \chi \omega \rho \varepsilon ́ \omega$ 'I withdraw', not only is there no reference to a prior event, but there can never have been any such event.

In the face of this difficulty, some have rejected entirely the notion of reference to a prior event as an element of the semantics of the perfect per se. Accordingly Porter (1989:259) offers the following summary of the semantics of the perfect:

While there may be reference to a previous act that results in a state or condition, this is a matter of lexis in context. The aspect [of the perfect] itself merely represents the state or condition of the grammatical subject, as conceptualized by the speaker or writer.

Porter is certainly right that, if these present-state referring perfects are to be integrated into the semantics of the perfect, reference to a prior terminated or culminated event cannot be inherent to the semantics of the perfect itself. However, Porter's attempt to disregard efforts to explain those cases where the perfect does carry past time reference by integrating accounts of the perfect with lexical aspect may be misguided. Considerable progress has in fact been made by paying close attention to lexical aspectual differences, as we shall see below.

Complicating matters is the undoubted diachronic development of the semantics of the Greek perfect, first denoting anteriority, then denoting perfective aspect, so that it finally disappears, having merged with the aorist. The precise dating of the start of this change, however, is in dispute, with a variety of opinions among scholars ranging from the early post-Classical period, ${ }^{17}$ through to the 4 th- 5 th centuries AD. ${ }^{18}$ Many have accordingly taken a predominantly diachronic approach of the semantics of the perfect, and do not attempt to give a single semantic definition for the perfect in the later language that is capable of encompassing all instances of it. These scholars see the instances of present-only perfects in the later language, in the period of the New Tes-

17 e.g. Horrocks (2010:131, $176 \mathrm{f}$.).

18 e.g. Porter (1989:273), McKay (1981:289). 
tament, for instance, as lexicalised vestiges of a former fully stative system. ${ }^{19}$ Consider the following definition from Turner (1963:81-82, 83), quoted from Porter (1989:252):

The Aktionsart belonging properly to the [Perfect] tense is either fulfilment in the present of a process begun in the past or else the contemplation of an event having taken place in the past with an interval intervening ... It is therefore a combining of the Aktionsarten of the aorist and the present. Originally it had no resultative force but simply expressed the subject's state; this had been arrived at by some previous activity, but the state arrived at was represented by the perfect as so permanent that the perfect can be said from long before the NT period to have present meaning ... the old intrans. perfect was giving way before the active, transitive and resultative pf. ... and its meaning is difficult to distinguish from the aorist.

The question of the semantics of the perfect in the later post-Classical language turns therefore on the analysis of present-state only perfects: if these are still to be accounted for within the semantic framework of the perfect system, this should be considered evidence that temporal semantics, in particular anteriority, cannot play a role in the semantic definition of the perfect. If, on the other hand, the present-state only type is to be seen as a group of lexicalised exceptions, the path is clear to analyse the core semantic definition of the perfect in terms of anteriority. It is the purpose of the present article to test each of these positions.

Perfects bearing no anterior time reference are formed principally to verbs occurring in two semantic categories: a) those introducing telic predicates, as in change-of-state and change-of-position verbs, of the type illustrated by $\alpha \nu \alpha \chi \omega \rho \tilde{\varepsilon} \omega$ 'to withdraw' in example (4) above, and b) those introducing stative predicates, such as the state verb $\gamma \eta \theta^{\varepsilon} \omega$ 'to be happy'. ${ }^{20}$ If Porter is right that the

19 For example Chantraine (1927:216), discussing the use of the perfect $\pi \dot{\varepsilon} \pi \circ \theta \alpha$ in the NT, notes that 'cette forme n'est plus étroitement liée au present $\pi \varepsilon i \theta_{0} \mu \alpha$ l... en effet les parfaits intransitifs de ce type tendaient à devenir des presents indépendents.' Cf. Porter's (1989:256) summary of Turner's position as one of 'minimiz[ing] the perseverance of the Perfect and its aspectual function in the NT era, except for a few stereotyped forms.' Gerö \& von Stechow (2003:254) almost entirely exclude so-called intensive perfects from their investigation, and claim that in the post-Classical period the type does not exist (2003:281).

20 The case of the perfect of the idiosyncratic group of noise verbs is necessarily left out of 
perfect denotes the state or condition of the subject, the behaviour of the first group of perfects becomes explicable. However, if this is the case, why should a perfect exist at all for the second group? And given that it does exist, what can be said to be the difference in the semantic terms between the present and the perfect? Haug (2004:394), who is concerned primarily with the situation in Homeric and Classical Greek, summarises the difficulty as follows:

There are some verbs for which this relationship [viz. where the perfect denotes the result of a past event that has terminated] never holds. Such verbs have a so-called intensive or abnormal perfect. We can give as an example the verb gêthein 'be happy.' The present gèthei means 'he is happy,' the aorist egèthēse 'he became happy,' and the perfect gegèthe means 'he is happy.' ... The perfect tense is abnormal in that it seems to have the same meaning as the present.

To illustrate the problem, consider the following examples (provided by The Chicago Homer project [http://digital.library.northwestern.edu/homer/]):

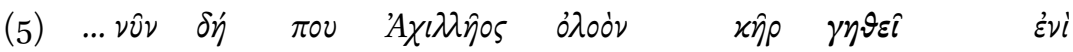
... now PTCL PTCL of-Achilles destructive heart rejoice.PRES in $\sigma \tau \eta^{\prime} \vartheta \varepsilon \sigma \sigma l \ldots$

breast

'I suppose now the destructive heart in Achilles' breast is happy ...' IL. 14.139f. Text: MONRO, 1902

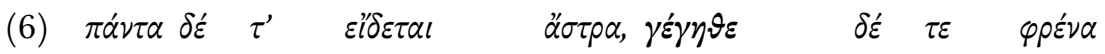
all and PTCL appear.PRES stars, rejoice.PERF and PTCL in-mind $\pi \circ \mu \eta^{\prime}$...

shepherd

'And all the stars appear, and the shepherd is glad in mind.' IL. 8.559. Text: MONRO, 1902

In example (5) the present of $\gamma \eta \theta^{\prime} \omega$ is used to describe the state of Akhilleus. The very same sentiment, however, appears to be conveyed by the perfect in (6).

consideration for the purposes of the present article because there are no examples in the NT translated into Gothic. 
Haug (2004:394f.) attempts a solution to this problem by proposing to derive the semantics of the perfect of state verbs from the aorist, rather than the present. This works because the aorist of pure state verbs such as $\gamma \eta \dot{\varepsilon} \omega$ may, in its ingressive sense, denote entry into the state described by the lexical verb. Accordingly, the perfect would then denote the state resulting from the event denoted by the aorist, which is, in the case of $\gamma \eta \dot{\varepsilon} \omega$, happiness. In this way the semantics of the perfect of state verbs can be integrated with those of verbs introducing telic predicates, given that in both cases the perfect may be said to denote the state entered as described by the aorist. This provides a single explanation for why it is possible in both cases for the perfect to denote a state without reference to a prior culminated event, as may be seen by comparing

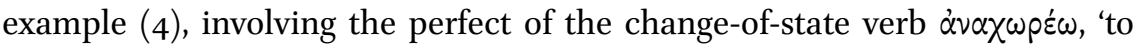
withdraw', with that of $\gamma \eta \theta \dot{\varepsilon} \omega$ in (5) and (6). ${ }^{21}$

Accordingly, Haug (2004:395f.) describes the semantics of the perfect in the Homeric and Classical periods as follows:

[T] he perfect denotes a present state resulting from a former event that can be expressed by the VP in the aorist. The perfect, therefore, has a double reference: a present state and a past event that culminated. But, as we would expect in such situations, pragmatic factors can put emphasis on the state or on the event.

It follows from this that the difference in semantic terms between the present and the perfect is the capacity for the latter but not the former to refer to a prior culminated event. A key test for this proposal, therefore, is the existence of perfects formed to state verbs which carry past time reference. This test will become very important in what follows.

With the arrival of the later Classical and early post-Classical periods, however, the semantics of the perfect system undergo significant change. Verbs describing events linguistically realised as atelic predicates, i.e. where the subject is not presented as undergoing a change of state or position, such as $\gamma p \alpha \dot{\alpha} \varphi \omega$ 'I write', did not in the earliest periods have perfects formed to them in Greek. ${ }^{22}$ In the late Classical and post-Classical periods, however, these start to receive

21 Questions remain, however, as Haug notes. In particular, what is the semantic relationship between the perfect and the present in such cases, given that 'intensivity' is not a reliable reading?

22 This follows Haug's use of the term 'atelic' (Haug 2004:408), where the telicity of a predicate refers to whether or not the predicate "give[s] rise to a state of the subject". 
perfect forms of their own. Because it is often difficult to construe a state as resulting from an atelic predicate, Haug proposes that an $\mathrm{XN}$-interpretation evolved for these verbs. Though it may appear at first sight that the perfect has no unitary semantic in this period, Haug (2004:409ff.) suggests that the two semantics may be unified under a single semantic by exploiting the notion of event realisation, ${ }^{23}$ by which "events that fall under atelic predicates are realized as soon as they have begun, as long as the interval considered is large enough for the event to count as an instance of the predicate." Accordingly Haug (2004:410) summarises the function of the perfect in the Classical and early post-Classical periods as follows: "the perfect of a predicate $\mathrm{P}$... refers to the state resulting from the event denoted by $\mathrm{P}$ (in the perfective aspect) being realized."

Here, as Haug (2004:410) himself notes, the term 'state' must be taken broadly, inasmuch as in the case of atelic predicates it is unclear what state could be referred to. Furthermore, as we have seen from example (4), there is in fact no requirement for such a prior event to have taken place at all, at least in the later post-Classical language. For our purposes, therefore, it is necessary to offer the following modified formulation of $\mathrm{a}(\mathrm{n}$ at this stage hypothetical) unitary semantic operating in the later post-Classical language, such as that which we find in the NT:24 "The perfect of a predicate P denotes a property of the subject $S$ as a function of $S$ existing at or beyond a terminal point of the event as determined by the event structure ${ }^{25}$ of P."

This proposal differs from Haug's formulation in the following ways for the purpose of describing the situation in the later post-Classical period:

a) It removes the requirement for a prior event to have been realised, reducing this merely to a requirement that subject exists at or beyond a terminal point of the event as determined by the event structure construed from the verb and its arguments. If the event is bounded on the right by a state, the subject is construed as existing in this state.

23 Citing Bohnemeyer \& Swift (2001), now published as Bohnemeyer \& Swift (2004). For them (2004:283) the "realization" of an event "amounts to what is meant in ordinary English by saying that an event occurs or happens" (italics theirs).

24 This formulation is a development of that given in Crellin (2012b).

25 The term 'event structure' used here does not take a view on where this structure originates, whether in the lexical content of the verb, or in the verb's syntactic context. See e.g. Dölling, Heyde-Zybatow \& Schäfer (2008:ix f.) for references to the relevant literature on event structure. 
b) The notion of 'state' is replaced with that of 'property', adopting Smith's (1997) formulation of the perfect as denoting a property of the subject participant (see $n .9$ above). ${ }^{26}$ In perfects introducing telic predicates, this property is naturally interpreted as referring to the target state which holds for the subject at the terminal point. In atelic predicates, however, where no target state is clearly defined, the property may naturally be interpreted simply as a (necessarily past) experience of the subject.

The combination of removing the requirement for event realisation, and having the perfect return a property of the subject rather than a state, gives the semantic sufficient flexibility to account for the observed behaviour. It provides a framework, for example, to explain why the perfect of $\alpha \nu \alpha \chi \omega \rho \varepsilon \dot{\varepsilon} \omega$ might both carry the implication of a prior terminating event, and also be incompatible with such a notion, according to whether or not the property of the function is required to generate a prior terminating event in order to be construed in context. Similarly, it allows for verbs introducing accomplishment (i.e. bounded) predicates without post-states, such as $\pi \circ \varepsilon \varepsilon$, to carry anterior reference, given that the only construable property of the subject is that of the terminated event as a past experience of the subject.

Haug's framework describes the situation seen in the Classical and early post-Classical periods. It is the purpose of the following sections to assess to what extent our formulation might be said to be valid for the later post-Classical period, specifically in New Testament Greek. The investigation addresses the following question: is there evidence that the semantics of perfects of state verbs, and those of verbs introducing telic predicates, are in this period productively derived along the lines predicted our formulation presented above? The extent to which this is true will provide evidence that the perfect has not yet developed into an anterior. The evidence sought will come from the Gothic translation of the NT, and it is to discussion of the Gothic verb system that we now turn.

A major difficulty to be faced by any linguist concerned with ancient languages is the lack of living consultants. However, this does not mean that we are completely without the testimony of native speakers of ancient languages. Beyond the direct testimony of the ancients in the form of commentaries on the meanings of other texts, ancient translations also offer a valuable window into

26 This participant property notion differs, of course, from that of Smith in removing the requirement for the subject to have participated in an event prior to reference time, in accordance with a) above. 
how individual forms and words were read in antiquity. An important aspect of the present article is that it uses a form of testimony that has not to my knowledge been brought to bear on this question, namely the testimony of the early versions of the NT. ${ }^{27}$ In these we have evidence from people standing much closer to the time of writing than modern scholars in the form of the ancient versions. The specific aim of this article is to assess the evidence for the perfect being understood with a unitary semantic in Wulfila's fourth century translation of the New Testament into Gothic. Before proceeding, however, it is important to establish Wufila's trustworthiness as a source of information on this matter.

2

Wulfila's Reliability as a Translator

The Gothic New Testament is a good source of the kind of evidence needed. According to the Letter of Auxentius, its translator, Wulfila, preached in Greek, Latin and Gothic, and indeed produced written material in all three. ${ }^{28}$ While, as Burton (2002:393) notes regarding Wulfila's knowledge of Latin, some caution is in order given the clearly eulogising nature of the Letter, this level of familiarity with Greek fits with what we known of Wufila's ancestry and background. Wulfila grew up among the Goths, but was of Cappadocian descent, his ancestors having been captured in a Gothic raid. ${ }^{29} \mathrm{He}$ was evidently sufficiently conversant in Greek, however, to enable him to be appointed among a group of ambassadors to the Empire, a trip which led to him being appointed bishop of the Gothic Christians ${ }^{30}$ at the age of thirty. ${ }^{31}$

Wulfila's translation is consistent with someone who understood Greek idioms. ${ }^{32} \mathrm{~A}$ case in point is his translation of $2 \mathrm{Co} 11: 25$ at (7), where a wooden word-for-word translation of the idiomatic $v \nu \chi \theta \dot{\eta} \mu \varepsilon p o v \pi \varepsilon \pi o^{\prime} \eta \chi \alpha$ is avoided:

27 For another investigation comparing using translational material from the NT as a guide to the interpretation of the verb system of a language see $\mathrm{Li}$ (2010). In this case, however, the Greek is used to establish the meaning and use of Syriac verb forms.

28 See Burton (2002:393) for quotation of the relevant section of the letter, and textual references.

29 Philostorgius Historia Ecclesiastica 2.5 .

$30 \quad$ Philostorgius Historia Ecclesiastica 2.5 .

$31 \quad$ Letter of Auxentius, see Kauffmann (1899:75).

32 For Wulfila's practice of not translating Greek idioms literally see Burton (2002:404). 


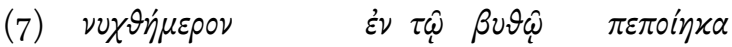

a-night-and-a-day in the deep I-make.PERF-ACT

naht jah dag in diupipai was mareins

night and day in deep I-be.PRET-ACT of-sea

'I was in the deep of the sea a night and a day.'

2 CO 11:25 B

Wulfila's treatment of verbal categories as well as syntax is likewise consistent with a sensitivity to the subtleties of the Greek language. Although it is clear that Wulfila stayed very close to the Greek as far as strict word order is concerned, ${ }^{33}$ in syntax in general (Klein 1992), and in the translation of verbal-aspectual and tense distinctions in particular, the translator retained freedom. ${ }^{34}$ Not only this, but in the way he uses this freedom it is clear that he has an understanding of their nuances in Greek. The Greek future is a case in point. The Proto-Germanic verb system, and that of Gothic in particular, had no formal future tense (Meillet 1922:161; Kotin 2012:291) with the future often conveyed by what is often called the 'present' tense form, but which we refer to as the 'non-past'. ${ }^{35}$ Indeed, Wulfila does not ignore the distinction between the present and the future when it occurs in Greek, however, using other categories in Gothic instead to bring out nuances that are important for the understanding of the text. Consider (8) below, where he employs the perfectivising $g a$ - prefix to render the future, and to avoid an otherwise trivial statement if the same non-past verb forms were used throughout. ${ }^{36}$

33 See Drinka (2011:55), who also quotes Friedrichsen (1926).

34 See Drinka (2011:55 ff.); Klein (1992) comments on the translation of the aorist in Greek by means of $g a$ - prefixed forms (p. 346), and on the treatment of other verbal categories (p. 36off.).

35 On the past $\sim$ non-past distinction see Comrie (1985:48f.).

36 On the future rendered by $g a$-, see inter alios Harbert (2007:297) and Kotin (2012:298f.). The view is not without its detractors, however, e.g. Wedel (1997:322) who cites Hinsdale (1897) and Lawson $(1965,1966)$, whose research, however, appears principally based on OHG. 
(8) $\dot{\varepsilon} \lambda \varepsilon \dot{\eta} \sigma \omega$

I-have-pity.FUT-IND

gaarma

ga-PREFIX-I-take-pity.PRES-IND whom

xai oix

CONJ I-have-mercy.FUT-IND

jah gableipja

ò $\quad \ddot{\alpha} \nu \quad \dot{\varepsilon} \lambda \varepsilon \hat{\omega}$

whom PTCL I-have-pity.PRES-SUBJ

panei

arma

CONJ ga-PREFIX-I-have-mercy.PRES-IND whom

oixtipw

I-have-mercy.PRES-SUBJ

bleipja

I-have-mercy.PRES-IND

'I will take pity on whom I take pity, and I will have mercy on whom I have mercy.'

Rom. 9:15 A

In other places, Wulfila does translate the future with a bare non-past form. Yet, in these cases, other strategies are adopted to convey the futurity. At Mt 6:26, given at (9) below, the future sense is brought out through the use of a telic predicate, ${ }^{37}$ translating $\varphi \omega \tau \varepsilon เ v o \nu v ~ \varepsilon ̋ \sigma \tau \alpha l$ with liuhadein wairpip, instead of liuhadein ist, to render futurity by means of default aspect. ${ }^{38}$

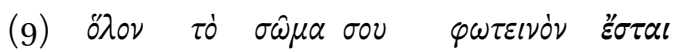
whole the body of-you light be.FUT

allata leik pein liuhadein wairpip

all body your light become.PRES

'Your whole body will become light.'

Mt 6:26 CA

This is not to say that Wulfila always distinguishes the Greek future from the present. Yet where the distinction is not made, it is at least in some cases possible to see why. Compare the following two examples:

37 Kotin (2012:291 f.). Kotin distinguishes telic and non-telic verbs. However, I take telicity to be a property of predicates, with the expectation or not of an endpoint encoded by the verb itself to be terminativity.

38 On default aspect see Bohnemeyer \& Swift (2004). 


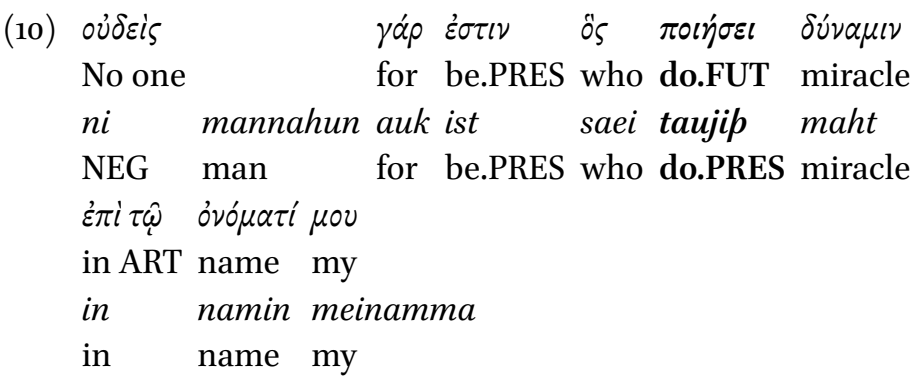

'For there is no one who does a miracle in my name ...'

Mk 9:39 CA

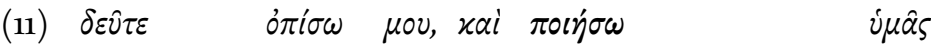

come.IMPV behind me, and I-make.FUT you

hirjats afar mis, jah gatauja igqis

after me, and ga-PREFIX-I-do.PRES you

$\gamma \varepsilon \nu \varepsilon \dot{\sigma} \vartheta \alpha l \quad \dot{\alpha} \lambda \iota \varepsilon \hat{\imath} \varsigma \quad \dot{\alpha} \nu \vartheta \rho \omega \dot{\pi} \omega \nu$.

become.AOR-INF fishers of-men.

wairpan nutans manne.

become.INF fishers of-men.

'Come after me, and I will make you fishers of men.'

Mk 1:17 CA

$\pi \circ \eta \dot{\sigma} \sigma \omega$ in (11) describes an event situated at a time point after the previous event: if the addressees follow Jesus, he will, subsequently, turn them into

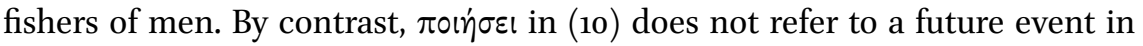
the same way; Jesus is describing a general truth, namely that no one can, now or in the future, do a miracle in his name, and then slander Jesus. ${ }^{39}$ Wulfila's sensitivity to the meaning of the Greek future in context makes the way in which he translates the Greek perfect, a form which, like the future, has no formal equivalent in Gothic, of great potential interest.

It is in Wulfila's role as bishop of the Gothic Christians that he embarked upon the translation of almost the whole Bible into Gothic. ${ }^{40}$ Although the translation was made some three hundred years after the original composition of the documents that later went to make up the NT, Wulfila stands much closer to the original time of writing than modern interpreters. To the extent,

\footnotetext{
39 Indeed, the modern English versions (ESV, NIV, NRSV) all translate with the present tense.

40 Philostorgius Historia Ecclesiastica 2.5, Jordanes Getica 51.267, Socrates Scholasticus Historia Ecclesiastica 4.33.
} 
therefore, that a clear picture emerges of Wulfila's interpretation of the perfect, his interpretation should be weighed carefully against modern ones that do not have such privileged access to native or near-native instincts.

In specific terms, this article sets out to assess the evidence in Wulfila's translation for a unitary perfect semantic operating at the time of the New Testament. Before this can be done, however, it is important to understand how the verb system in Gothic is structured, and consequently what translations we might expect to find. This follows after a brief outline of the texts and translations used in the course of this investigation.

For Greek the 2010 SBL Greek New Testament (SBLGNT) text was used (http:// www.sblgnt.com) as a base text. This text is used because it is freely distributable and therefore it is possible to write code to interrogate it. Perfects were found using a Java application written by the author, whose results were crosschecked with other software using Nestle-Aland 27 (NA27).$^{41}$ Due to the affinity borne by the Gothic translation to the Byzantine Greek text, Gothic translations of the Greek perfect were only included if they occurred at locations where both $\mathrm{NA} 27$ and the Byzantine text had a perfect. ${ }^{42}$ In practice this led to twelve occurrences of the perfect in NA27 being excluded. ${ }^{43}$

For Gothic the text of Streitberg (1919) was used in the electronic form provided by the Wulfila Project (http://www.wulfila.be/). The principal MSS from which the Gothic evidence for the NT is derived, with abbreviations, are:

- Codex Argenteus (CA)

- Codex Ambrosianus A (A)

- Codex Ambrosianus B (B)

Because of the paucity of Gothic evidence, when Gothic quotations are given, the source MSS are also given as provided by the Wulfila Project.

41 SBLGNT and NA27 differed in terms of perfect indicative actives within the corpus at one

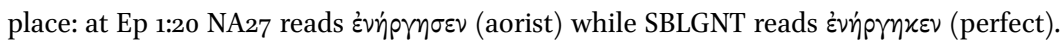
NA27 was provided by BibleWorks 7.0.

42 Byzantine text is that of Robinson and Pierpont (1995), provided by BibleWorks 7.0.

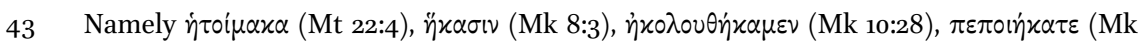

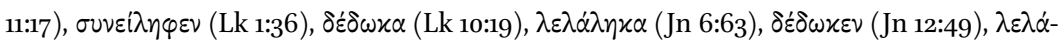

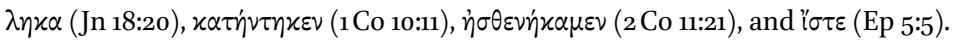


Translations are my own. In section 4, which sets out the structure of the Gothic verb system, translations are given of the Gothic in the light of the Greek. From that point on, translations of are given of the Greek in the light of the evidence provided by Gothic.

\section{Structure of the Gothic Verb System in Terms of Tense and Aspect}

The Gothic verb system, as in Germanic generally, demonstrates a binary opposition in tense terms between past and non-past, formally represented by the preterite and non-past tense forms respectively (Kotin 2012:291, Meillet 1922:124). The present denotes present situations, as well as denoting timeless truths and the habitual (Kotin 2012:292). The following gives an example of the latter:

(12) unte ik patei leikaip imma tauja sinteino because I that which please him do.PRES always

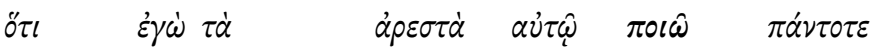
because I the pleasing to-him do.PRES always 'Because I always do what pleases him.' Jn 8:29 CA

This straightforward opposition is complicated in at least two respects. First, there exists a special group of so-called preterite-present verbs, whose formal preterite is used to denote a present state of affairs. These descend directly from the inherited PIE perfect, which originally had stative sense, and are therefore cognate with the Greek perfect (Ringe 2006:153 ff.). A secondary preterite is then used to denote the past for these verbs.

Secondly, although a future tense is not formally distinguishable in Gothic, as was demonstrated earlier in example (9), in 'default aspect' phenomena paralleled in modern German (Bohnemeyer \& Swift 2004:270), future time may be indicated by translation by means of a telic predicate. ${ }^{44}$ Table 1 (next page) gives an overview of the tense system in Gothic.

The Gothic verb system can denote aspectual oppositions through prefixes, including, but not limited to, the prefix ga-(Kotin 2012:294). Thus in many cases the Greek aorist corresponds to the $g a$ - prefixed form: ${ }^{45}$

\footnotetext{
44 See n. 37 on Kotin's distinction between telic and non-telic verbs.
}

45 For more examples and discussion, see Kotin (2012:299f.). 


\begin{tabular}{l|c|c|c|c}
\hline \multirow{2}{*}{ Predicate type } & \multicolumn{3}{|c|}{ Regular } & Preterite-present \\
\cline { 3 - 4 } & \multirow{2}{*}{ Telic } & Activity & State & - \\
\cline { 3 - 5 } Non-past & $\begin{array}{c}\text { Present/ } \\
\text { Future }\end{array}$ & Present activity & Present state & - \\
\hline Preterite 1 & Past & Past activity & Past state & \multirow{2}{*}{ Present } \\
\hline Preterite 2 & - & - & - & Past \\
\hline
\end{tabular}

(13) managans auk gahailida

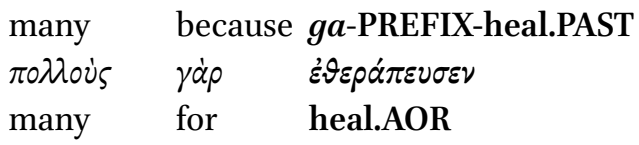

'For he healed many.'

Mk 3:10 CA

Although there is no formally distinguished future tense in Gothic, in behaviour familiar from Slavonic languages, the $g a$ - prefix form is often found to denote future time, as was shown above at example (8) above. However, the extent to which the $g a$ - prefix may be regarded as perfectivising per se is still the subject of controversy (Kotin 2012:294). At issue is the degree to which the $g a$-prefix may be said to be grammaticalised. While there is certainly correlation between $g a$ - prefixation and perfective interpretation, in some cases it is clear that $g a-$ retains its original sociative meaning:

(14)

\begin{tabular}{|c|c|c|c|c|}
\hline gawaurstwans & sijum & & anstais & izwaraizos \\
\hline ga-PREFIX-co-worker & we-be.PRES & & joy & your \\
\hline 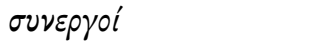 & $\dot{\varepsilon} \sigma \mu \varepsilon \nu$ & $\tau \hat{\eta} \varsigma$ & xapâs & $v \mu \omega \nu$ \\
\hline co-worker & we-be.PRES & of-the & of-joy & of-you \\
\hline
\end{tabular}

It is also the case that the prefixation of $g a$ - does not always correspond to the use of the aorist in the Greek text, given that there are clear instances of the 
Greek aorist translated by a Gothic verb form without prefix, where the Greek form clearly denotes a single event which terminated prior to reference time:46

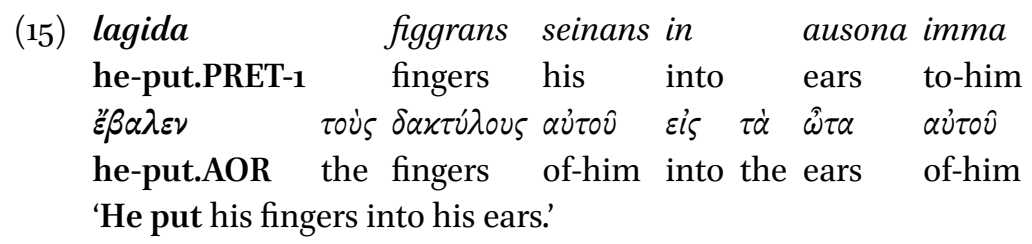

Mk 7:33 CA

Gothic for the most part does not demonstrate independent use of the verb haban 'to have' construed with the past participle to denote the perfect, as would later develop in the other Germanic languages, Latin (and daughters) and Celtic. ${ }^{47}$ Drinka (2011:6o ff.) does identify two examples of apparently independent use of the construction, at $1 \mathrm{Ti} 4: 2$ and $2 \mathrm{Ti}$ 2:26, but these are attributed to Latin influence at a later stage in these particular manuscripts. ${ }^{48}$ Otherwise, where have-perfects occur in the Gothic text, they always parallel a Greek construction with है $\chi \omega$ and past passive participle. ${ }^{49}$

To summarise, we may say that the Gothic verb system clearly distinguishes past and non-past time, with the added flexibility of marking a category which bears some relation to perfective aspect in Greek aspect through $g a$ - prefixation. In the course of this investigation, the primary variable used to test the perceived semantic value of the Greek perfect will be the Gothic past nonpast distinction. This is because key to the present investigation are the conditions under which the Greek perfect does, or does not, refer to time prior to

46 For these reasons some scholars, in particular Lloyd (1979), who is followed by Wedel (1997), have been at pains to avoid the term 'perfective' when referring to the semantics of the Gothic ga- prefixed forms, preferring the term 'complexive' instead. The latter term is used so as to emphasise a distinction between Russian and Germanic expressions of aspect, whereby the former may denote the beginning of an event, a function which is foreign to ga- prefixed forms in Germanic (Wedel 1997:323).

47 See Drinka (2011:59) and Meillet (1922:129).

48 On the issue of Old Latin influence on the text, although without reference specifically to tense-aspect distinctions, see Friedrichsen (1939) and also Burton (2002:404) who concludes: "while it is easy to point to formal correspondences between Latin and Gothic, and while in many cases it would be easy to explain one version with reference to the other, this is seldom the only plausible explanation."

49 Drinka (2011:59). For the possible Latin influence on this construction in Greek see Horrocks (2010:131f.). 
reference time. Inasmuch as $g a$ - prefixation does not affect the semantics of the Gothic verb in terms of anteriority, it will not occupy a major place in the argument that follows.

5

Method

The corpus used to investigate the Greek perfect was the set of all synthetic perfect indicative actives in that part of the Greek NT for which there was a Gothic translation in the indicative. The investigation was restricted to the Greek perfect active system, because this is where the majority of morphologically 'old' perfects may be found, i.e. those perfects formed at a stage in the language where the productive meaning of the perfect was stative. These perfects therefore have the potential to preserve this stative sense as an archaism. ${ }^{50}$ Restricting the investigation to active perfects does not compromise it, however, because among active perfects it is possible to find verbs of all three types with which this investigation is concerned, namely state, change-of-state and non-state verbs, discussed further below.

The translation of Greek periphrastic perfects falls beyond the scope of the present investigation, insofar as it does not follow that these perfects should have the same semantics as their synthetic counterparts. Nevertheless, the translation of periphrastic perfects deserves an investigation in its own right. ${ }^{51}$ Only those Greek perfect forms translated by Gothic indicatives were considered so that the temporal relations were clear.

For the purposes of the investigation, Greek verbs are divided into two main groups: state verbs, i.e. those verbs which introduce predicates where the subject exists in or enters into a state, and non-state verbs, where the subject enters into no such state, and whose predicates are always atelic. The group of state verbs is further subdivided into pure state and change-of-state verbs. Pure state verbs are those verbs, like $\eta \eta \varepsilon^{\prime} \omega$, which in the present introduce atelic predicates, while in the (ingressive) aorist introduce telic predicates. Change-of-state verbs are by contrast those verbs, like $\dot{\alpha} v \alpha \omega \rho \tilde{\varepsilon} \omega$, which denote a change of state or position, and which introduce telic predicates both in the

5o These 'old' perfects are as opposed to perfects which entered the language in the later Classical and post-Classical language where stativity was, at least according to many views, no longer the only semantic value attributable to the form.

51 For a recent study of the semantics of periphrastic perfects in Ancient Greek see Bentein (2012), which, however, is concerned only with the situation up to and including the 4 th century BC. 
present and in the aorist. ${ }^{52}$ This group also comprises verbs denoting possessive change-of-state such as $\lambda \alpha \mu \beta \alpha$ ' $\nu \omega$ 'I take', as well as defective state verbs that do not exhibit a full paradigm, such as oî $\alpha$ 'I know'. 53

Finally, for the purposes of this investigation I will not exploit the difference between change-of-state and causative change-of-state verbs. Suffice it to say that so far as one can posit a mechanism by which, in the case of causativechange-of-state, the external argument may be suppressed or removed in the case of the perfect, the causative change-of-state type may be analysed as a sub-class of the change-of-state type. ${ }^{54}$ Table 2 (next page) gives the various subtypes involved and examples.

Excluded were verbs whose semantic type is ambiguous or polysemous with

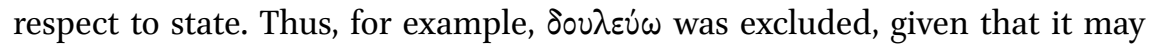
carry both a stative meaning 'to be a slave' and a non-state meaning 'to render a service. ${ }^{55}$ The two views of the Greek perfect to be tested in this investigation are as follows:

a. Anterior: the Greek perfect has developed into a true perfect, with presentonly cases such as $0 i \delta \alpha$ 'I know', $\pi \dot{\varepsilon} \pi 01 \theta \alpha$ 'I trust' etc. to be treated as lexicalised exceptions.

52 The following are the Vendlerian equivalents of these terms (Vendler 1957). 'Pure state'

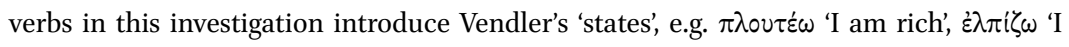

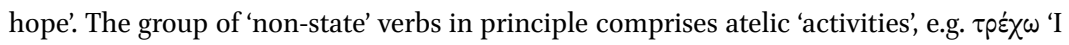

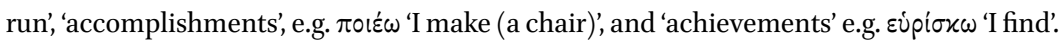
It should be noted, however that in practice there were no perfects of activity verbs in the corpus. Finally 'change-of-state' verbs introduce telic 'accomplishments', e.g. $\sigma \dot{\eta} \pi \circ \mu \alpha$ l (perf. $\sigma \dot{\varepsilon} \sigma \eta \pi \alpha$ ) 'I go rotten', and 'achievements', e.g. $\gamma \curlyvee \gamma \nu \omega \sigma \kappa \omega$ 'I come to know, recognise'.

53 Note that defective state perfects such as oi $\delta \alpha$ cannot be categorised according to the type of predicate, whether telic or atelic that they introduce, because there are no existing full paradigms for comparison.

54 For a similar approach to this problem, see Haug (2004:403), who cites Sæbø (2001) in relation to the anticausative alternation.

55 See LSJ ad loc. Also excluded on these grounds were: $\pi \alpha p \alpha x \circ \lambda \circ \nu \theta \varepsilon \dot{\varepsilon} \omega$, meaning both nonstate 'I follow closely' and change of state 'I understand'; $\mu \varepsilon \tau \varepsilon$ ' $\chi \omega$, meaning both state 'I

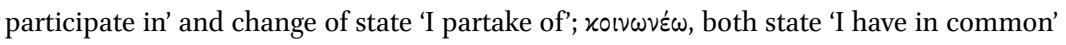
and non-state 'to do in common with'; $x$ i iv $\omega$, both change of state 'I decide' and non-state

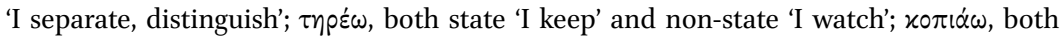
change of state 'I grow weary' and non-state 'I work hard'; ó $\alpha \omega \omega$ 'I see' was excluded because of the ambiguity generated by verbs of 'seeing', for which see Vendler (1957:154ff.); $\alpha$ xoú $\omega$ 'I hear' was excluded because of the similarity of its semantics to ópów. 
TABLE 2 Greek lexical aspectual categories

\begin{tabular}{|c|c|c|c|c|c|}
\hline Category & $\begin{array}{l}\text { Predicate } \\
\text { type }\end{array}$ & Semantic type & Meaning & & Perfect active \\
\hline \multirow[t]{6}{*}{ State } & Telic/atelic & Pure state & $\pi \lambda \circ \nu \tau \varepsilon \dot{\varepsilon} \omega$ & I am rich & $\pi \varepsilon \pi \lambda \circ v^{\prime} \tau \eta \alpha \alpha$ \\
\hline & & & $\dot{\varepsilon} \lambda \pi i \zeta \omega$ & I hope & $\eta \eta \lambda \pi i x \alpha$ \\
\hline & Telic & $\begin{array}{l}\text { Change-of- } \\
\text { position }\end{array}$ & 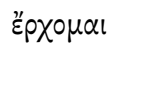 & I come & $\dot{\varepsilon} \lambda \dot{\eta} \lambda \nu \theta \alpha$ \\
\hline & & $\begin{array}{l}\text { Possessive } \\
\text { change-of-state }\end{array}$ & $\lambda \alpha \mu \beta \alpha^{\prime} \nu \omega$ & $\begin{array}{l}\text { I take, } \\
\text { receive }\end{array}$ & $\varepsilon ं \lambda \eta \varphi \alpha$ \\
\hline & & $\begin{array}{l}\text { Causative } \\
\text { change-of-state }\end{array}$ & $i \sigma \tau \eta \mu \iota$ & $\begin{array}{l}\text { I make to } \\
\text { stand }\end{array}$ & 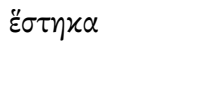 \\
\hline & - & Defective & - & I know & oî $\alpha$ \\
\hline Non-state & Atelic & & $\pi \circ \varepsilon^{\prime} \omega$ & $\begin{array}{l}\text { I make, } \\
\text { produce }\end{array}$ & $\pi \varepsilon \pi o^{\prime} \eta \eta \alpha$ \\
\hline
\end{tabular}

b. Participant property: Semantic definition as at p. 14 above, namely: "The perfect of a predicate $P$ denotes a property of the subject $S$ as a function of $S$ existing at or beyond a terminal point of the event as determined by the event structure of P." This formulation encapsulates both (result) state and anterior readings in one semantic.

Given the sketch of the Gothic verb system in $\S 4$, how might we establish to which of these two hypotheses Wulfila considered the verb system of NT Greek to belong?

The behaviour of the perfect of non-state verbs should, according to both hypotheses a) and b), produce past-tense readings in Gothic. If the NT perfect is a true perfect, one should expect all perfects, including those formed to non-state verbs, to be read as anteriors. Similarly, according to hypothesis b) presented earlier, the anterior reading is logically the only possible result for the subject of an atelic predicate, inasmuch as there is no construable target state: the only property that can result for the subject is the experience of having participated in the event in past time. 
The difference between the hypotheses should become apparent, however, in the case of state verbs. If, according to Wulfila, the perfect in the NT is a true perfect, according to hypothesis a), with the present-state only meaning of the perfect to be analysed as a lexicalised exception, we should expect to see some distinction between present-state only perfects first created when the stative reading was productive, and perfects formed to state verbs for the first time in the later post-Classical period. Specifically, in this scenario the former group should be translated into Gothic with past tense forms, as these should be being read as anteriors, the now productive meaning of the perfect, while perfects first formed to state verbs when the semantics of the perfects, such as $\pi \dot{\varepsilon} \pi \circ \bullet \theta \alpha$, translated with present tense forms.

According to hypothesis b), however, perfects formed to change-of-state verbs, such as $\theta v \dot{\eta} \sigma \kappa \omega$, and pure state verbs, such as $\gamma \eta \theta \dot{\varepsilon} \omega$, should be interpretable with both non-past and past tense forms in Gothic alike, because these are derived semantically in the same way, as statives with or without direct reference to a prior culminating event. Although this follows straightforwardly from the analysis, it is contrary to the communis opinio that the perfect of state verbs may carry no past semantics.

The following diagnostic questions will help in our analysis. First:

1. Are state verbs interpreted with non-past tense forms in Gothic?

An answer to this in the affirmative will confirm the existence of perfects with non-past interpretations, at least in Wulfila's eyes. An answer in the negative, however, will provide evidence that this type does not exist at this stage of the language. If the type exists, we can ask:

2. Do these perfects formed to state verbs continue an older stage of the Greek language, or are they new formations?

The answer to this question will establish whether or not we are dealing with a continuing productive semantic category in Greek in later post-Classical period, or a lexicalised exception. The key behaviour to check will be that of perfects attested first in the post-Classical period, such as $\eta \lambda \pi i x \alpha$, from $\dot{\varepsilon} \lambda \pi i \zeta \omega$, 'I hope', ${ }^{56}$ given that the semantics of these should represent the productive meaning of the perfect in this period. If these perfects are translated with a non-past form in Gothic, this will constitute evidence that their pres-

56 A search of TLG shows that the perfect active of this verb is attested first in the NT. 


\begin{tabular}{|c|c|c|c|}
\hline Perfect semantics & $\begin{array}{l}\text { Non-state } \\
\text { e.g. } \pi \varepsilon \pi 0^{\prime} \eta \eta n \alpha\end{array}$ & $\begin{array}{l}\text { State (old form) } \\
\text { है } \tau \eta \eta x \alpha\end{array}$ & $\begin{array}{l}\text { State (new form) } \\
\eta \lambda \pi เ \kappa \alpha\end{array}$ \\
\hline
\end{tabular}

$\begin{array}{llll}\text { a) Anterior } & \text { Past } & \begin{array}{l}\text { Non-past or Past, ac- } \\ \text { cording to lexical item }\end{array} & \text { Past } \\ \text { b) Participant } & \text { Past } & \begin{array}{l}\text { Non-past or Past, irre- } \\ \text { spective of lexical item }\end{array} & \begin{array}{l}\text { Non-past or Past, irre- } \\ \text { spective of lexical item }\end{array}\end{array}$

ent state semantics were still productively derived in the later post-Classical language.

Furthermore, if we are correct to describe the semantics of the perfect in this period as presented in hypothesis b), we would expect not only to find these perfects translated with non-past forms in Gothic, but also with past tense forms, inasmuch as the semantics of these perfects, with the potential for the imposition of a terminal point prior to reference time, should behave in exactly the same way as those of change-of-state verbs, where there is an expectation of an endpoint. Indeed, if this line of reasoning is correct, and if the system is genuinely productive at this time, we should find past and non-past readings not only in perfects created in the post-Classical period, but also in

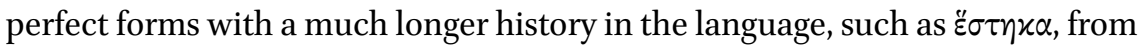
¿ $\sigma \tau \eta \mu$. The diagnostic questions relevant here will be the following:

3. Are there verbs whose perfects are read both as non-past and past tense forms in Gothic? If so:

a. What are their semantics? Specifically, are there members of both pure state and change-of-state categories?

b. What is the age of their attestation? Specifically, are there both new formations and old stative perfects which behave in this way?

If both of these questions are answered in the affirmative, it will constitute strong evidence for the regular and systematic treatment of present-only state verbs in Greek, i.e. hypothesis b), concomitantly providing evidence against hypothesis a) that these perfects either do not exist in this period or are lexicalised exceptions.

Table 3 gives a summary of the expected readings of the different lexical verb types in the terms of the Gothic tense system according to hypotheses a) and b). 


\section{$6 \quad$ Results}

Table 4 gives the overall results of the translation of the perfect into Gothic according to semantic type, and Table 5 gives the breakdown by lexical item.

TABLE $4 \quad$ Numerical results for translation of Greek perfect into Gothic

Semantic verb group (Greek)

Total

\begin{tabular}{|c|c|c|c|c|c|c|}
\hline $\begin{array}{l}\text { Tense } \\
\text { form }\end{array}$ & $\begin{array}{l}\text { Verb group } \\
\text { (Gothic) }\end{array}$ & Non-state & Pure state & $\begin{array}{c}\text { Change-of-state/ } \\
\text { position }\end{array}$ & Defective & \\
\hline \multirow[t]{2}{*}{ Pres. } & Regular & & 1 & 10 & & 11 \\
\hline & Pret.-pres. & & & 1 & 97 & 98 \\
\hline \multirow[t]{2}{*}{ Pret. } & Regular & 64 & 13 & 46 & & 123 \\
\hline & Pret.-pres. & & & 5 & 2 & 7 \\
\hline Other & & 1 & & 2 & & 3 \\
\hline Total & & 65 & 14 & 64 & 99 & 242 \\
\hline
\end{tabular}

TABLE 5 Numerical results for translation of Greek perfect into Gothic: breakdown by lexical item

\begin{tabular}{|c|c|c|c|c|c|c|}
\hline Gothic form & Greek verb & Gloss & Non-state & Pure state & Change-of-state & Defective \\
\hline \multirow[t]{6}{*}{ pres. ind. act. } & $\dot{\alpha} \nu \theta^{\prime} \sigma \tau \eta \mu l$ & 'set against' & & & 1 & \\
\hline & $\varepsilon \varphi \dot{i} \sigma \tau \eta \mu l$ & 'set upon' & & & 1 & \\
\hline & $\dot{\varepsilon} \lambda \pi i \zeta \omega$ & 'hope' & & 1 & & \\
\hline & ï $\sigma \tau \eta \mu$ & 'set up' & & & 3 & \\
\hline & $\pi \alpha p i \sigma \tau \eta \mu l$ & 'set beside' & & & 1 & \\
\hline & $\pi \varepsilon i \theta \omega$ & 'persuade' & & & 4 & \\
\hline pret.-pres. pres. & $\gamma(\gamma \nu \omega \dot{\sigma} \alpha \omega$ & 'recognise' & & & 1 & \\
\hline \multirow[t]{2}{*}{ ind. act. } & oî $\alpha$ & 'know' & & & & 96 \\
\hline & $\sigma \dot{v} v o 1 \delta \alpha$ & 'be aware' & & & & 1 \\
\hline
\end{tabular}


TABLE 5 Numerical results for translation of Greek perfect into Gothic (cont.)

\begin{tabular}{|c|c|c|c|c|c|}
\hline Gothic form & Greek verb & Gloss & Non-state & Pure state & Change-of-s \\
\hline \multirow[t]{33}{*}{ pret. ind. act. } & $\alpha \nu o i ́ \gamma v u \mu l$ & ‘open’ & & & 2 \\
\hline & $\dot{\alpha} \nu \theta^{\prime} i \tau \tau \mu \iota$ & 'set against' & & & 1 \\
\hline & $\dot{\alpha} \pi \circ \sigma \tau \varepsilon \dot{\varepsilon} \lambda \omega$ & 'send' & 2 & & \\
\hline & $\alpha ו p \omega$ & 'raise' & 1 & & \\
\hline & 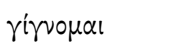 & 'become' & & & 16 \\
\hline & $\delta i \delta \omega \mu t$ & 'give' & 18 & & \\
\hline & हैpXo $\mu \alpha 1$ & 'come' & & & 12 \\
\hline & $\varepsilon \chi \chi \omega$ & 'have' & & 3 & \\
\hline & 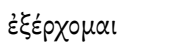 & 'come out' & & & 1 \\
\hline & 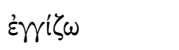 & 'approach' & & & 5 \\
\hline & $\dot{\varepsilon} \chi \pi i ́ \tau \tau \omega$ & 'fall out' & & & 1 \\
\hline & $\dot{\varepsilon} \lambda \pi i \zeta \omega$ & 'hope' & & 3 & \\
\hline & 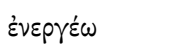 & 'work' & 1 & & \\
\hline & i $\sigma \tau \eta \mu \iota$ & 'set up' & & & 3 \\
\hline & $\lambda \varepsilon^{\prime} \gamma \omega\left(\varepsilon^{\prime \prime} p \eta \varkappa \alpha\right)$ & 'say’ & 4 & & \\
\hline & $\varkappa \alpha \lambda \varepsilon^{\prime} \omega$ & 'call' & 2 & & \\
\hline & $x \alpha \tau \alpha \beta \alpha i v \omega$ & 'go down' & & & 2 \\
\hline & $\varkappa \alpha \tau \alpha p \gamma \varepsilon \dot{\varepsilon} \omega$ & ‘destroy’ & 1 & & \\
\hline & $\lambda \alpha \lambda \varepsilon^{\prime} \omega$ & 'speak' & 11 & & \\
\hline & $\lambda u \pi \varepsilon^{\prime} \omega$ & 'upset' & 2 & & \\
\hline & 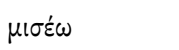 & 'hate' & & 2 & \\
\hline & $v i x \alpha \dot{\alpha} \omega$ & 'defeat' & 1 & & \\
\hline & $\pi \varepsilon^{\prime} \theta \omega$ & 'persuade' & & & 1 \\
\hline & $\pi เ \sigma \tau \varepsilon v^{\prime} \omega$ & 'believe' & & 4 & \\
\hline & $\pi \lambda \eta p o ́ \omega$ & 'fill' & 2 & & \\
\hline & $\pi \circ \mid \varepsilon ́ \omega$ & 'make, do' & 5 & & \\
\hline & $\begin{array}{l}\pi \rho \circ \lambda \varepsilon \dot{\gamma} \omega \\
(\pi \rho \circ \varepsilon i \rho \eta \varkappa \alpha)\end{array}$ & 'say beforehand' & 4 & & \\
\hline & $\theta \nu \eta \dot{\sigma x \omega}$ & 'die’ & & & 2 \\
\hline & $\sigma \omega^{\prime} \zeta \omega$ & 'save’ & 7 & & \\
\hline & $\tau \varepsilon \lambda \varepsilon^{\prime} \omega$ & 'complete' & 1 & & \\
\hline & $\tau i \theta \eta \mu \iota$ & 'place' & 1 & & \\
\hline & $\tau \cup \varphi \lambda o ́ \omega$ & 'blind' & 1 & & \\
\hline & $\varphi\left(\lambda \varepsilon^{\prime} \omega\right.$ & 'love' & & 1 & \\
\hline
\end{tabular}




\section{Gothic form Greek verb Gloss Non-state Pure state Change-of-state Defective}

\begin{tabular}{|c|c|c|c|c|c|c|}
\hline pret.-pres. pret. & $\gamma(\gamma \nu \omega \dot{\sigma} \sigma \omega \omega$ & 'recognise' & & & 5 & \\
\hline ind. act. & oî $\delta \alpha$ & 'know' & & & & 2 \\
\hline & Other 57 & & 1 & & 2 & \\
\hline Total & & & 65 & 14 & 64 & 99 \\
\hline Grand Total & & & & & & 242 \\
\hline
\end{tabular}

In terms of the state / non-state distinction, these results confirm the expected general picture for both hypotheses outlined above: while state verbs are capable of interpretation either as past or non-past tense forms in Gothic, non-state verbs may be translated only by past tense forms. Of non-state verbs, the following example is typical:

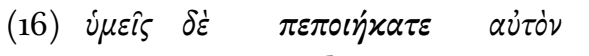
you CONJ make.PERF it den of-robbers ip jus gatawidedup ita du filigrja waidedjane CONJ you make.PRET-1 it into den evildoer 'But you have made it a den of robbers.'

Mk 11:17 CA

Similarly expected are the following cases involving the perfects of i $\sigma \tau \eta \mu \mathrm{r}$ and $\theta v \eta \dot{\sigma} \sigma \omega$ :

57 Included in 'other' are: $\tau \dot{\varepsilon} \theta \eta \nu x \varepsilon \nu(1 \mathrm{Ti} 5: 6)$ translated by copula and adjective daupa ist given

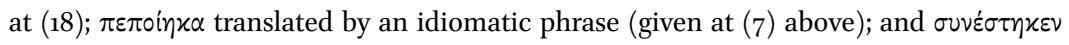
(Co 1:17) translated by past particle and copula ussatida sind. This latter potentially represents a periphrastic 'be' resultative which would later become much more common in Germanic. Given that this is the only example found in this investigation, however, establishing the place of this construction in the Gothic verb system will require a dedicated study. On periphrastic perfects in Gothic focusing on the 'have' type see Drinka (2011). 


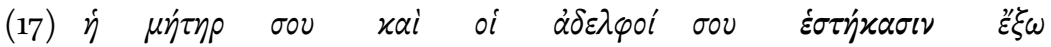
the mother of-you CONJ ART brothers of-you set-up.PERF outside aipei peina jah broprjus peinai standand uta mother your CONJ brothers your stand.PRES outside 'Your mother and your brothers are standing outside' Lk 8:20 CA

(18) $\dot{\eta} \quad \delta \dot{\varepsilon} \quad \sigma \pi \alpha \tau \alpha \lambda \hat{\omega} \sigma \alpha$

the CONJ live-in-indulgence.PRES-PTPL

ip so wizondei in azetjam

CONJ DEM wallow.PRES-PTPL in pleasures

xai $\zeta \hat{\omega} \sigma \alpha \quad \tau \varepsilon \dot{q} \eta \eta x \varepsilon \nu$

ADV live die.PERF-IND

jah libandei daupa ist

CONJ live.PRES-PTPL dead be.PRES-IND

'But the one who wallows in pleasure, though she lives, is dead.'

1Ti 5:6 A, B

Other change-of-state verbs, whose resulting state is strongly associated with a prior event, as in the case of change-of-location verbs, are regularly translated with past tense forms in Gothic:

(19) $\dot{\alpha} \pi^{\prime} \quad \dot{\varepsilon} \mu \alpha v \tau \odot \hat{v} \quad$ ơ $\delta \dot{\varepsilon} \quad \dot{\varepsilon} \lambda \dot{\eta} \lambda u \vartheta \alpha$

from myself NEG I-come.PERF

fram mis silbin ni qam

from me self NEG I-come.PRET-1

'I did not come from myself.'

Jn 8:42 CA

So far the picture is consistent with both hypotheses a) and b), and indeed the traditional picture of the perfect system in Greek. A good starting point for making progress in distinguishing between the two is to look at the behaviour of pure state verbs, and then consider the state verb group as a whole. Specifically, according to the diagnostic questions above, we need to establish whether:

1. The perfects of pure state verbs are interpreted with non-past forms in Gothic.

2. These perfects continue an older stage of the Greek language or are new formations.

3. There are perfects read both as non-past and past tense forms in Gothic. 
TABLE 6 Frequency of translation of state perfects by means of Gothic non-past form

\begin{tabular}{|c|c|c|}
\hline Verb & State verb subtype & Frequency \\
\hline$\alpha \nu \theta^{\prime} \sigma \tau \eta \mu l\left(\dot{\alpha} \nu \varepsilon^{\prime} \sigma \tau \eta \kappa \alpha\right)$ & Causative change-of-state & 1 \\
\hline$\gamma(\gamma \nu \omega \dot{\sigma} \sigma \omega$ & Change-of-state & 1 \\
\hline$\dot{\varepsilon} \varphi i^{\prime} \sigma \tau \eta \mu l(\dot{\varepsilon} \varphi \dot{\varepsilon} \sigma \tau \eta \varkappa \alpha)$ & Causative change-of-state & 1 \\
\hline$\dot{\varepsilon} \lambda \pi i \zeta \omega$ & Pure state & 1 \\
\hline ï $\tau \eta \mu l$ & Causative change-of-state & 3 \\
\hline oî $\delta \alpha$ & Defective state perfect & 96 \\
\hline 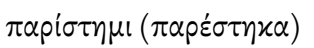 & Causative change-of-state & 1 \\
\hline$\pi \varepsilon^{\prime} \theta \omega\left(\pi \varepsilon^{\prime} \pi \circ \bullet \theta\right)$ & Causative change-of-state & 4 \\
\hline 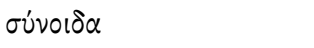 & Defective state perfect & 1 \\
\hline Total & & 109 \\
\hline
\end{tabular}

From Table 4 it will be seen that one example was found of the perfect of pure state verb translated by a non-past tense form in Gothic. Table 6 reveals this verb to be $\dot{\varepsilon} \lambda \pi i \zeta \omega$.

The example in question is the following:

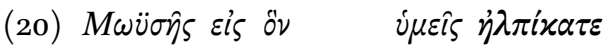

Moses in whom you you-hope.PERF

Moses du pammei jus weneip

Moses to whom you you-hope.PRES

'He who accused you is Moses in whom you hope.'

Jn 5:45 CA

This case answers the first of our diagnostic questions, and shows that in principle the perfect of state verbs even as late as the NT may be interpreted as bearing no time reference to any point prior to reference time. It also answers the second diagnostic question, given that, according to TLG, the perfect of $\dot{\varepsilon} \lambda \pi i \zeta \omega$ is not attested before the New Testament. Indeed, the verb itself is not attested before the Classical period. $\eta \lambda \pi i \kappa \alpha$ is therefore very unlikely to be archaic vestige, but rather a case of the productive creation of a state perfect bearing no reference to time prior to reference time.

Having found this instance of the perfect of a pure state verb translated as a non-past, it is important to ask if it is also translated in Gothic with a 
past tense, insofar as this will provide evidence of productive interpretation of perfects of state verbs along the lines predicted by Haug's analysis. Indeed, three examples of $\ddot{\eta} \lambda \pi i \kappa \alpha$ translated by a past tense in Gothic can be found, of which the following is an example: 58

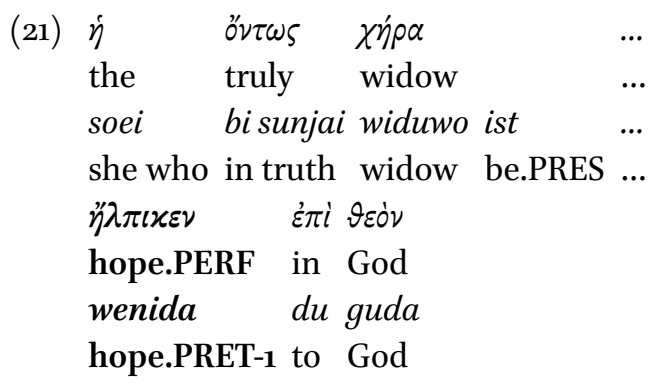

'She who is in truth a widow has put her hope in God.' 1 Ti $5: 5$ B

The broader context in 1 Timothy is the need to identify correctly the true widow, where the point being made is that trust in God is a criterion for identification. In this context it makes no sense for the widow to have ceased hoping in God at reference time, and so we must here be dealing with a resultative reading. It is not hard to see how past reference is appropriate: the widow's present 'true widowhood' is predicated on her previous hoping in God (which still continues). ${ }^{59}$ However, the role of the context in this case raises the possibility that it is in fact the perceived temporal relatioship to other events in context that resolves the question of past-time reference in the Greek perfect for the translator, and that this is the factor that determines whether or not the perfect is interpreted as past-referring or not in the other cases.

The perfect of pure state verbs, then, is translated into Gothic exactly as one would expect according to hypothesis b). It remains to be seen, however, to what extent the attribution of past reference to all verbs in the state verb category, especially old change-of-state verbs, is productive in this period. To test this, it is useful to know which perfects in the corpus are translated by both presents and preterites into Gothic. This information is given in Table $7{ }^{60}$

$5^{8} \quad$ The other examples may be found at 2 Co 1:10 and 1 Ti 4:10.

59 It is interesting to compare this translation with that of the KJV which translates with a present.

6o The perfect active of ópd́w is also translated on one occasion by a present tense, namely 
TABLE $7 \quad$ First attestation of Greek perfect indicative actives translated by both non-past and past forms in Gothic

\begin{tabular}{|c|c|c|c|}
\hline Verb & Non-past & Past & $\begin{array}{l}\text { First attestation of } \\
\text { perfect active (TLG) }\end{array}$ \\
\hline$\dot{\alpha} \nu \theta^{\prime} \sigma \tau \eta \mu l(\dot{\alpha} \nu \theta \varepsilon \sigma \tau \eta \kappa \alpha)$ & 1 & 1 & Homer \\
\hline$\gamma(\gamma v \omega \dot{\sigma} \sigma \omega$ & 1 & 5 & Pindar \\
\hline$\varepsilon \lambda \pi i \zeta \omega$ & 1 & 3 & NT \\
\hline$\theta v \dot{n}^{\prime} \sigma \omega^{61}$ & 1 & 2 & Homer \\
\hline$i \sigma \tau \eta \mu l(\varepsilon ี \sigma \tau \eta \kappa \alpha)$ & 3 & 3 & Homer \\
\hline oîं $\alpha$ & 96 & 2 & Homer \\
\hline$\pi \varepsilon i \theta \omega(\pi \dot{\varepsilon} \pi \circ \mid \theta \alpha)$ & 4 & 1 & Homer \\
\hline Total & 107 & 17 & \\
\hline
\end{tabular}

As expected, this group consists entirely of state verbs. Strikingly, however, it includes a number of old change-of-state verbs, namely i $\sigma \tau \eta \mu,, \theta \nu \eta \dot{\sigma} \sigma \omega, \pi \varepsilon i \theta \omega$ $(\pi \varepsilon \dot{\varepsilon} \pi(\theta \alpha)$, and, notably, oi $0 \alpha$. It is possible to see that individual state verbs are translated both by past and non-past forms in Gothic, and that, with the exception of oi $\delta$, perfects in this group are more likely to be translated with a past tense in Gothic than a non-past, facts that go against expectation according to hypothesis a).

It is noteworthy that this group includes state verbs of differing semantic types: pure state $(\dot{\varepsilon} \lambda \pi i \zeta \omega)$, change-of-state verbs $(\theta v \dot{\eta} \sigma x \omega$ and $\gamma(\gamma v \omega \dot{\sigma} \sigma \kappa \omega)$, and causative change-of-state verbs $(\pi \varepsilon i \theta \omega$ and $i \sigma \tau \eta \mu)$. The following are examples of $\pi \varepsilon i \theta \omega$ and i $\sigma \tau \eta \mu$ respectively:

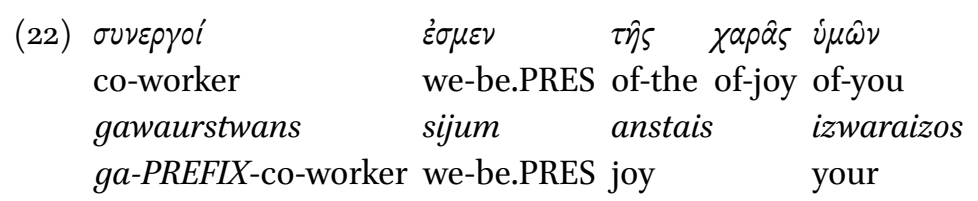

gasaihvip at Jn 14:7. As noted at n. 54 ópów was excluded from this investigation because of the ambiguities over the statehood of certain perception verbs. The translation of this verb into Gothic merits an independent investigation.

61 For these purposes copula + adjective daupa ist is treated as a non-past tense. 
$\tau \hat{\eta} \quad \gamma \dot{\alpha} \rho \quad \pi i \sigma \tau \varepsilon l \quad \dot{\varepsilon} \sigma \tau \dot{\eta} \varkappa \alpha \tau \varepsilon$

ART PTCL by-faith you-set-up.PERF

unte galaubeinai gastopup

PTCL by-faith you-stand.PRET-1

'We are co-workers of your joy, for by faith you have taken your stand.' ${ }_{2}$ Co. 1:24 A, B

(23) $\pi \dot{\pi} \pi 0$ เงะข

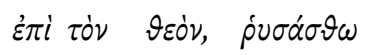

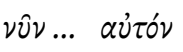

he-persuade.PERF in in ART God trauaida $d u$ guda lausjadau him he-trust.PRET-1 to God deliver.IMPV-3sg 'He has put his trust in God, let him deliver him now.' Mt 27:43 CA

In (22) the present tense context strongly encourages a resultative rather than anterior reading, i.e. 'We are co-workers of your joy, for you have stood (and are still standing) by faith.' Nevertheless, the fact that a past tense form is used in Gothic shows that at least for the translator there was some past time reference. Similarly in (23) a resultative reading is most likely: 'He has put his trust in God; let him deliver him now.' 62

As expected, the vast majority of occurrences of oi $\delta \alpha$ are translated by (preterite-) presents. ${ }^{63}$ Even here, though, oi $\delta \alpha$ is on occasion deemed capable of carrying past time reference: 64

62 From a Gothic point of view it is striking that while there is a complementary distribution of the $g a$ - prefix and the preterite in the case of trauan, in the case of standan this complementary distribution is reversed, so that the $g a$ - prefix only occurs in the preterite

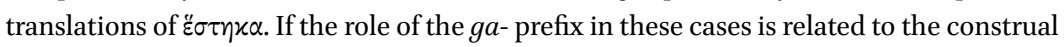
of endpoints, this complementary distribution could indicate different event structures in the predicates of the two verbs concerned. However, A separate investigation would be necessary to establish the truth of this suggestion.

63 A wide range of preterite-presents are used to translate these verbs, namely kunnan (25 examples), lais (2 examples), magan (1 example), witan (67 examples, including one example of mipwitan, translating $\sigma \dot{v} v o เ \delta \alpha$ ). The restriction of the preterite-present class to translation of oi $\delta \alpha$ and its compounds is striking given the supposed common semantic origin at the Indo-European level of the preterite-present class and Greek stative perfect (Ringe 2006:153), and it shows the extent to which either one or both verb systems have developed independently.

64 The other example is at $2 \mathrm{Ti} 3: 15$. 


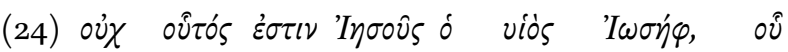

NEG DEM is Jesus the son of-Joseph of-whom

niu sa ist Iesus sa sunus Iosefis, pizei

NEG DEM is Jesus the son of-Joseph of-whom

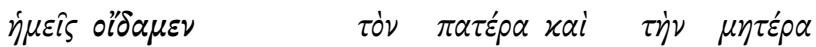

we we-know.PERF ART father CONJ ART mother

weis kunpedum attan jah aipein

we we-know.PRET-2 father CONJ mother

'Is this not the son of Joseph, whose father and mother we have known?'

Jn 6:42 CA

This is quite remarkable, and runs counter to both modern and traditional views of the place and function of supposedly very archaic perfects such as oi $\delta \alpha$ within the verb system. ${ }^{65}$ Insofar as this behaviour matches that demonstrated for the perfect of state verbs, it is consistent with the productive application of a unitary semantic along the lines of hypothesis b) even in the case of such archaic vestiges.

\section{$7 \quad$ A Unitary Semantic for the Perfect in the Later Post-Classical Period?}

The preceding analysis has provided answers to the diagnostic questions posed above. Specifically, we have found that state verbs of all semantic subcategories and of all diachronic depths are capable of being translated by both past and non-past tense forms into Gothic. This provides support for Haug's suggestion that the semantics of the perfect of pure state verbs should be derived in the same way as for change-of-state verbs, taking as a starting point the semantics of the aorist and not the present tense form. ${ }^{66}$

Furthermore, the fact that both new state perfects, such as $\ddot{\eta} \lambda \pi i x \alpha$, and forms with a much longer pedigree in the language, such as ह̈ $\sigma \tau \eta \varkappa \alpha$, behave in the same way demonstrates that as late as the fourth century, the same semantic rules were understood as being productively applied to state verbs

65 E.g. Goodwin (1895:270) who lists oî $\alpha$ under perfects with 'present meaning'. Cf. Porter's discussion (1989:255) where, citing the observations of a wide range of traditional grammars, uses the behaviour of oi $\delta \alpha$ and other verbs like it as a basis for his proposal for an atemporal semantic for the perfect.

66 For a recent analysis of the perfective imperfective opposition in Greek, see Bary (2009). 
of all semantic subgroups so as to generate both pure state and resultant state readings of perfects. This evidence suggests that we are in fact dealing with a productive semantic rule, at least in the case of state verbs.

Secondly, this investigation has provided evidence that the symbiosis of result-state readings and anterior readings for perfects of verbs introducing telic and atelic predicates respectively, which was observed by Haug for the Classical and early post-Classical periods, continued in much the same manner well into the post-Classical period, so that Wulfila translates the perfect active of these two verb types in a manner completely consistent with this analysis. In sum, the manner in which the Greek perfect is translated into Gothic is regular and predictable according to semantic type.

Finally, the consistency of the treatment of the perfect active by Wulfila was found to conform to the predictions of the semantic formulation for the perfect provided in hypothesis b) above, repeated here for convenience: "The perfect of a predicate $\mathrm{P}$ denotes a property of the subject $\mathrm{S}$ as a function of $\mathrm{S}$ existing at or beyond a terminal point of the event as determined by the event structure of P."

In the case of non-state verbs, i.e. those introducing bounded predicates without change of state for the subject, such as $\pi \circ \varepsilon \varepsilon \omega$, all instances are translated by past tense forms. This is exactly what we would expect if these were read as a property of the subject, construed as an experience, as a function of having participated in a prior event.

In the cases of the perfects of state and change-of-state verbs, however, we saw that both were equally capable of translation by past and non-past tense forms in Gothic, as shown in Table 7. Indeed this was found to be true both for perfect forms which entered the language at an early stage and those entering at a point in time much closer to the writing of the NT itself. This behaviour is also explicable in terms of hypothesis b), given that a property of the subject existing at or beyond the terminal point of the event as determined by the event structure of $\mathrm{P}$, without the requirement for event realisation, may be construed with or without reference to the terminal point itself. It has been suggested that in the final analysis it is the reader's interpretation of the temporal relationship that the predicate bears to other predicates in the immediate context that ultimately determines whether or not the perfect is seen to carry past reference. 


\section{Conclusion}

This article has analysed the translation of the Greek perfect indicative actives in the Gothic NT. It has found that, while non-state verbs are translated only with past-tense forms in Gothic, contrary to traditional and even many modern views of the Greek perfect, the perfect of both pure state and change-of-state verbs are compatible with past and non-past tense readings. This applies to verbs of this type regardless of when the perfect form entered the language. Insofar as it was possible to formulate a single semantic definition for the perfect, building on Haug 2004 and Crellin 2012b, which is fully consistent with the way in which it was translated by Wulfila, the evidence presented here strongly points to the conclusion that, at least in Wulfila's eyes, the perfect in the NT had this unitary semantic.

\section{Textual Sources}

Büttner-Wobst, Theodor. (Ed.). 1893-. Polybii historiae. Leipzig: Teubner.

Monro, David. B. (Ed.). 1902. Homer, Iliad. Vol. 1: Books 1-12. 3rd ed. Oxford: OUP.

Monro, David. B. (Ed.). 1902. Homer, Iliad. Vol. 2: Books 13-24. 3rd ed. Oxford: OUP.

Niese, Benedikt. (Ed.). 1892. Flavii Josephi Opera. Berlin: Weidmann.

Perrin, Bernadotte. (Ed.). 1914. Plutarch's Lives. (B. Perrin, Trans.) Cambridge, MA and London: William Heinemann Ltd.

Streitberg, Wilhelm. (Ed.). 1919. Der gotische Text und seine griechische Vorlage. Mit

Einleitung, Lesarten und Quellennachweisen sowie den kleineren Denkmälern als Anhang. Heidelberg: Carl Winter.

1993. Novum Testamentum Graece. 27. rev. Aufl., 2. Druck. Stuttgart: Deutsche Bibelstiftung.

2010. SBL Greek New Testament. Society of Biblical Literature and Logos Bible Software.

\section{References}

Bary, Corinne. 2009. Aspect in Ancient Greek: a semantic analysis of the aorist and imperfective. Ph.D. thesis, Radboud Universiteit Nijmegen.

Bentein, Klaas. 2012. The periphrastic perfect in Ancient Greek: a diachronic mental space analysis. Transactions of the Philological Society 11o(2): 171-211.

Bohnemeyer, Jürgen and Mary Swift. 2001. Default aspect: the semantic interaction of aspectual viewpoint and telicity. Proceedings of Perspectives on Apsect, Utrecht Institute of Linguistics. 
Bohnemeyer, Jürgen., and Mary Swift. 2004. Event realization and default aspect. Linguistics and Philosophy 27: 263-296.

Burton, Phillip. 2002. Assessing Latin-Gothic interaction. In: J.N. Adams, M. Janse, \& S. Swain (Eds.), Bilingualism in ancient Society, pp. 393-418.

Bybee, Joan L., Revere D. Perkins, and William Pagliuca. 1994. The Evolution of Grammar. Chicago: University of Chicago Press.

Campbell, Constantine R. 2007. Verbal Aspect, the Indicative Mood, and Narrative. New York: Peter Lang.

Chantraine, Pierre. 1927. Histoire du parfait grec. Paris: Société de linguistique de Paris. Comrie, Bernard. 1976. Aspect. Cambridge: CUP.

Comrie, Bernard. 1985. Tense. Cambridge: CUP.

Crellin, Robert. 2012a. Basics of verbal Aspect. Journal for the Study of the New Testament 35(2): 196-202.

Crellin, Robert. 2012b. The Greek Perfect Active System: 200 BC-AD 15o. Ph.D. thesis, University of Cambridge.

Cutrer, Michelle. 1994. Time and Tense in Narratives and everyday Language. Ph.D. thesis, University of California at San Diego.

Dölling, Johannes, Tatjana Heyde-Zybatow, and Martin Schäfer (Eds.). 2008. Event Structures in linguistic Form and Interpretation. Berlin: Walter de Gruyter.

Drinka, Bridget. 2011. The sacral stamp of Greek: periphrastic constructions in New Testament translations of Latin, Gothic, and Old Church Slavonic. In: E. Welo (Ed.), Indo-European Syntax and Pragmatics: contrastive Approaches, Vol. 3, pp. 41-73.

Evans, Trevor V. 2001. Verbal Syntax in the Greek Pentateuch. Oxford: OUP.

Fanning, Buist. 1990. Verbal Aspect in New Testament Greek. Oxford: OUP.

Friedrichsen, George W.S. 1926. The Gothic Version of the Gospels: a Study of its Style and textual History. London: OUP.

Friedrichsen, George W.S. 1939. The Gothic Version of the Epistles: a Study of its Style and textual History. London: OUP.

Gerö, Eva-Carin and Arnim von Stechow. 2003. Tense in time: the Greek Perfect. In: Words in Time: diachronic Semantics from different Points of View, pp. 251-294. Berlin: de Gruyter.

Goodwin, William W. 1895. A Greek Grammar. Basingstoke and London: Macmillan.

Harbert, Wayne. 2007. The Germanic Languages. Cambridge: Cambridge University Press.

Haspelmath, Martin. 1992. From resultative to perfect in Ancient Greek. Funcion 11-12: 187-224.

Haug, Dag T.T. 2004. Aristotle's kinesis / energeia-test and the semantics of the Greek perfect. Linguistics 42(2): 387-418.

Haug, Dag T.T. 2008. From resultatives to anteriors in Ancient Greek: on the role of paradigmaticity in semantic change. In: T. Eythorsson (Ed.), Grammatical Change 
and Linguistic Theory: The Rosendal papers, pp. 285-305. Amsterdam: John Benjamins Publishing Company.

Hinsdale, Ellen C. 1897. Ueber die Wiedergabe des lateinischen Futurums bei den althochdeutschen Uebersetzern des 8.-10. Jahrhunderts. Ph.D. thesis, Göttingen.

Horrocks, Geoffrey. 2010. Greek: A History of the Language and its Speakers, 2nd ed. Wiley-Blackwell.

Kauffmann, Friedrich. 1899. Texte und Untersuchungen zur Altgermanischen Religionsgeschichte, Vol. 1: Texte. Strassburg: Verlag von Karl J. Trübner.

Klein, Jared. 1992. On the independence of Gothic syntax, I: Interrogativity, complex sentence types, tense, mood, and diathesis. Journal of Indo-European Studies 20 : 339-379.

Kotin, Michail. L. 2012. Gotisch im (diachronischen und typologischen) Vergleich. Heidelberg: Unversitätsverlag Winter.

Lawson, Richard. H. 1965. The prefix gi- as a perfectivizing future significant in OHG Tatian. Journal of English and Germanic Philology 64: 90-97.

Lawson, Richard. H. 1966. Gi- as a futurizing prefix in the shorter Old High German interlinear works. Neuphilologische Mitteilungen 67: 234-242.

Li, Tarsee. 2010. The Syriac Active Participle and the Expression of the Past Imperfective and the Present. American Oriental Society 13o(2): 141-165.

Lloyd, Albert. 1979. Anatomy of the Verb. The Gothic verb as a Model for a unified Theory of Aspect, actional Types and verbal Velocity. Amsterdam: John Benjamins.

McCoard, Robert. W. 1978. The English Perfect: Tense Choice and pragmatic Inferences. Amsterdam: North-Holland.

McKay, Kenneth. L. 1965. The use of the ancient Greek perfect down to the end of the second century AD. Bulletin of the Institute of Classical Studies 12: 1-21.

McKay, Kenneth. L. 1980. On the perfect and other aspects in the Greek non-literary papyri. Bulletin of the Institute of Classical Studies 27(1): 23-49.

McKay, Kenneth. L. 1981. On the perfect and other aspects in New Testament Greek. Novum Testamentum 23(4): 289-329.

Meillet, Antoine. 1922. Caractères généraux des langues germaniques, 2nd ed. Paris: Hachette.

Nedjalkov, Vladimir P. 1988. Typology of Resultative Constructions. Amsterdam: John Benjamins.

Orriens, Sander A.J. 2009. Involving the Past in the Present. In: Discourse Cohesion in Ancient Greek, pp. 221-239. Leiden: Brill.

Parsons, Terrence. 1990. Events in the Semantics of English. Cambridge, MA: MIT Press.

Porter, Stanley. E. 1989. Verbal Aspect in the Greek of the New Testament. New York: Peter Lang.

Ringe, Donald. 2006. A linguistic History of English: from Proto-Indo-European to ProtoGermanic. New York: OUP. 
Sæbø, Kjell. J. 2001. An analysis of the anticausative alternation. Retrieved from http:// folk.uio.no/kjelljs/AAAoz.dvi.pdf

Sicking, Chris M.J. and Peter Stork. 1996. The synthetic Perfect in Classical Greek. In: Two Studies in the Semantics of the Verb in Classical Greek, pp. 121-245. Leiden: E.J. Brill.

Smith, Carlota S. 1997. The Parameter of Aspect, 2nd ed. Dordrecht: Kluwer.

Turner, Nigel. 1963. A Grammar of New Testament Greek: Syntax, Vol. 3. Edinburgh: T. \& T. Clark.

Vendler, Zeno. 1957. Verbs and Times. The Philosophical Review 66(2): 143-160.

Wackernagel, Jacob. 1904. Studien zum griechischen Perfektum. Göttingen: W.F. Kaestner.

Wedel, Alfred. R. 1997. Verbal prefixation and the "complexive" aspect in Germanic. Neuphilologische Mitteilungen 98: 321-332. 